\title{
Portrait of a Nabob: Graphic Satire, Portraiture, and the Anglo-Indian in the Late Eighteenth Century
}

\section{Christina Smylitopoulos}

Volume 37, numéro 1, 2012

Humour in the Visual Arts and Visual Culture: Practices, Theories, and Histories

L'humour dans les arts et la culture visuels : pratiques, théories et histoires

URI : https://id.erudit.org/iderudit/1066730ar

DOI : https://doi.org/10.7202/1066730ar

Aller au sommaire du numéro

Éditeur(s)

UAAC-AAUC (University Art Association of Canada | Association d'art des universités du Canada)

ISSN

0315-9906 (imprimé)

1918-4778 (numérique)

Découvrir la revue

Citer cet article

Smylitopoulos, C. (2012). Portrait of a Nabob: Graphic Satire, Portraiture, and the Anglo-Indian in the Late Eighteenth Century. RACAR : Revue d'art canadienne / Canadian Art Review, 37(1), 10-25.

https://doi.org/10.7202/1066730ar

\section{Résumé de l'article}

L'étude des portraits commandés entre la fin des années 1760 et les années 1790 met en lumière les premiers modèles britanniques s'identifiant à l'Orient à travers une myriade d'attributs, dont des vêtements d'inspiration indienne, une flore et une faune exotiques, des domestiques et des compagnons indiens, et des références aux plus célèbres sites de l'Inde. Dans les portraits de la dernière décennie du XVIII ${ }^{\mathrm{e}}$ siècle, les Britanniques possédant des intérêts en Inde insistèrent au contraire sur leur « britannité » en mettant l'accent sur leur tenue européenne, en se plaçant dans des décors dépourvus de paysages et en faisant plutôt référence à l'Inde en tant que dépendance administrative de l'Angleterre et lieu d'essor militaire ou commercial. L'écart qui se manifeste dans ce type de portrait suggère l'influence de la satire graphique, un médium faisant souvent appel à la métaphore et à l'ironie, et qui pouvait exprimer plus directement l'inquiétude grandissante de l'époque concernant les modes de représentation de soi. Cet essai explore comment l'humour au service de la critique peut, dans son excès même, influencer la réception des oeuvres antérieures, que les spectateurs perçoivent alors de façon anachronique comme des attaques contre les Britanniques liés à l'Inde. L'étude de l'impact qu'a eu la représentation satirique sur l'art du portrait enrichit à la fois notre compréhension de la satire graphique en contexte colonial et notre connaissance de l'histoire de la représentation de soi, contribuant ainsi à une meilleure conception du dix-huitième siècle anglais comme « culture de la visualité ".
Tous droits réservés @ C UAAC-AAUC (University Art Association of Canada | Association d'art des universités du Canada), 2012
Ce document est protégé par la loi sur le droit d'auteur. L'utilisation des services d’Érudit (y compris la reproduction) est assujettie à sa politique d'utilisation que vous pouvez consulter en ligne.

https://apropos.erudit.org/fr/usagers/politique-dutilisation/ 


\title{
Portrait of a Nabob: Graphic Satire, Portraiture, and the Anglo-Indian in the Late Eighteenth Century
}

\author{
Christina Smylitopoulos, Postdoctoral Research Associate, \\ Department of Exhibitions and Publications, Yale Center for British Art
}

\begin{abstract}
Résumé
L'étude des portraits commandés entre la fin des années 1760 et les années 1790 met en lumière les premiers modèles britanniques s'identifiant à l'Orient à travers une myriade d'attributs, dont des vêtements d'inspiration indienne, une flore et une faune exotiques, des domestiques et des compagnons indiens, et des références aux plus célèbres sites de l'Inde. Dans les portraits de la dernière décennie du XVIII ${ }^{e}$ siècle, les Britanniques possédant des intérêts en Inde insistèrent au contraire sur leur « britannité » en mettant l'accent sur leur tenue européenne, en se plaçant dans des décors dépourvus de paysages et en faisant plutôt référence à l'Inde en tant que dépendance administrative de l'Angleterre et lieu d'essor militaire ou commercial. L'écart qui se manifeste dans ce type de portrait suggère l'influence de la satire graphique, un médium faisant souvent appel à la métaphore et à l'ironie, et qui pouvait exprimer plus directement l'inquiétude grandissante de l'époque concernant les modes de représentation de soi. Cet essai explore comment l'humour au service de la critique peut, dans son excès même, influencer la réception des œuvres antérieures, que les spectateurs perçoivent alors de façon anachronique comme des attaques contre les Britanniques liés à l'Inde. L'étude de l'impact qu'a eu la représentation satirique sur l'art du portrait enrichit à la fois notre compréhension de la satire graphique en contexte colonial et notre connaissance de l'histoire de la représentation de soi, contribuant ainsi à une meilleure conception du dix-huitième siècle anglais comme « culture de la visualité ».
\end{abstract}

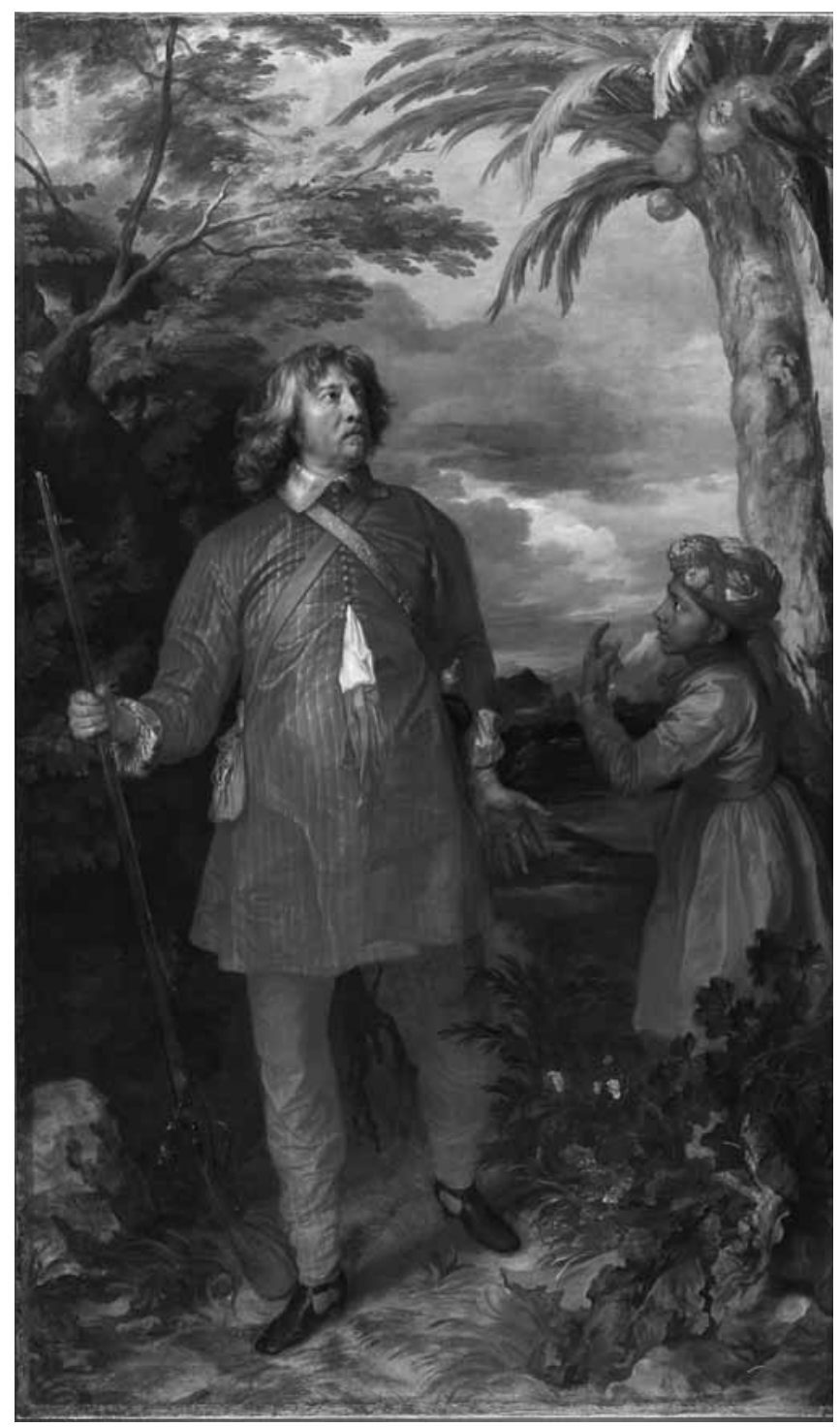

In Sir Anthony Van Dyck's full-length, life-size portrait of William Feilding, the first Earl of Denbigh, Feilding is depicted advancing through a pseudo-Indian landscape, resplendent in a full-length rose-pink silk jama, or surcoat, and matching paijamas (drawstring trousers), an ensemble forever complicated by black European shoes and a long flintlock rifle (ca. 1633-34; fig. 1). The size of the portrait and the status of the artist indicate that Feilding, the first English nobleman to tour India, was proud of his Indian expedition and wished to commemorate the experience on a grand scale. According to Feilding family mythology the young Indian servant directs the disoriented Englishman toward safety following a seemingly unproductive hunting trip, an interpretation that ignores the servant pointing out the green-winged macaw, a Van Dyck conceit incongruous to the landscape. ${ }^{1}$ I suggest that this peculiar shift of meaning may arise from the dramatic hybrid of English and Indian dress in which the sitter is depicted. This portrait represents one of the earliest and grandest examples of an English sitter identifying with the East through India-inspired apparel, a strategy of representation that, a century and a half later, would become closely associated with the satirical depiction of the nabob. In this paper I argue that India-related graphic satire, which lampooned the excesses of East India Company personnel, became so influential that over time it could even reduce an impressive full-length portrait of William Feilding into a caricature of a bewildered Eastern adventurer.

Figure I. Anthony van Dyck, William Feilding, First Earl of Denbigh, ca. 1633-34. Oil on canvas, 247.5 × 148.5 cm (Photo: (c) National Gallery, London / Art Resource, NY). 


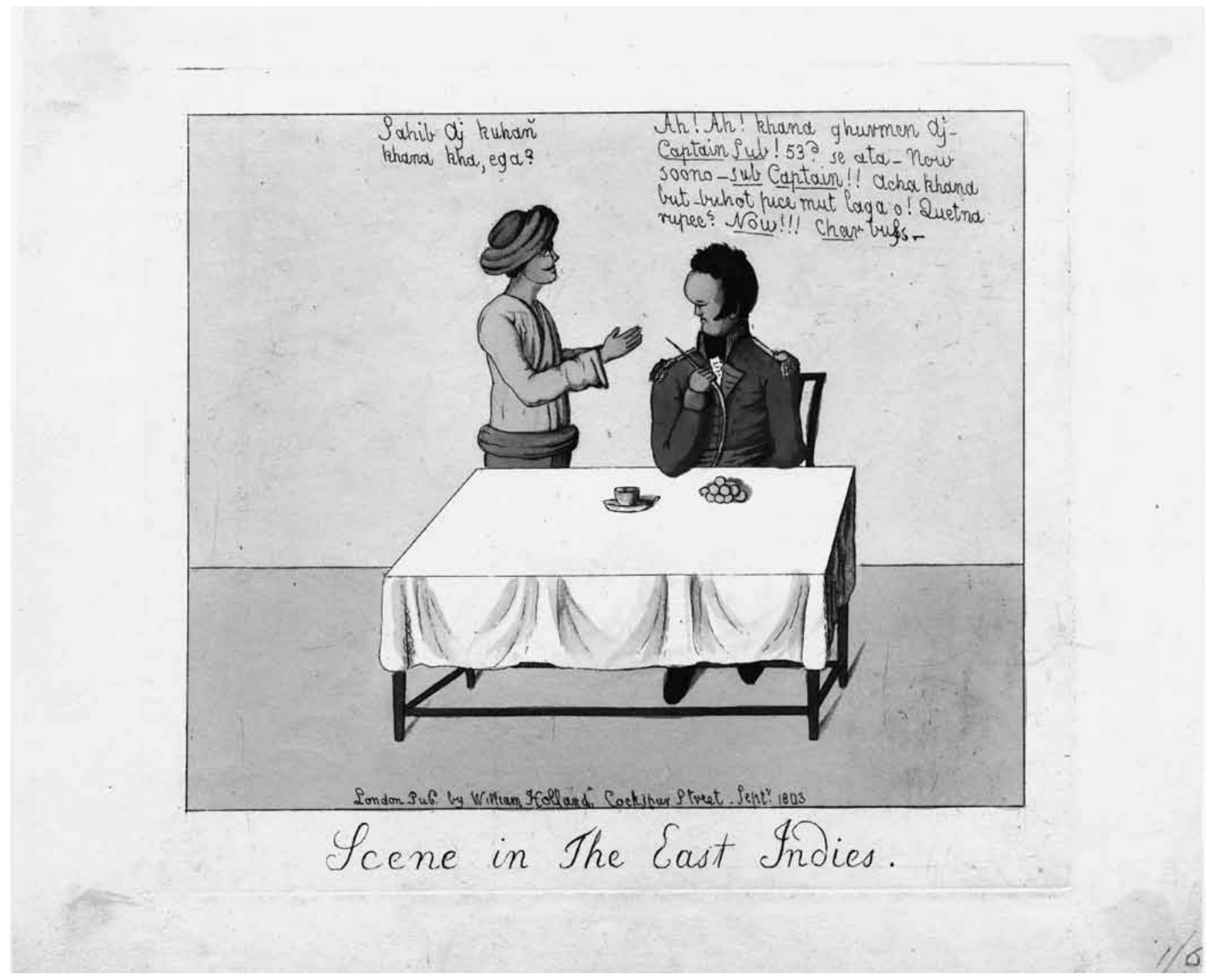

Figure 2. Anonymous, Scene in the East Indies, 1803. Etching and aquatint, with hand colouring, $22 \times 26 \mathrm{~cm}$ (Photo: Courtesy of The Lewis Walpole Library, Yale University).

The nabob was a significant subject in eighteenth-century British visual culture. An employee of the East India Company, the nabob was perceived to have returned to Great Britain equipped with ill-gotten affluence, a ravenous appetite for extravagance, and aspirations to rise into elite spheres of power and influence. ${ }^{2}$ When featured in graphic satire-a form of artistic print production which in this period in England applied ridicule, irony, sarcasm, and humour for "the correction of vice and improper conduct" and the "chastisement of immorality and folly" 3 - the figure of the nabob expressed domestic anxieties regarding a foreign, ad hoc empire in India. Contemporary accounts suggest that with "the spoils of Asia," the nabob had overstepped the prescribed socio-economic limit of his humble beginnings. ${ }^{4}$ In his freedom from his homeland's ethical constraints, the nabob had committed intemperance in eating "Curries and Peelaws" and drinking "India Madeira" and "arrack," the catch-all term for spirituous liquors of native manufacture in Eastern settings. 5 He was guilty of an extravagant violation of decency, law, and/or morality through outrageous conduct, and he transgressed the limits of moderation by acquiring resources "by art, fraud, cruelty, and imposition."6 Furthermore, when the figure of the nabob emerged in the 1760 s, the British had already established a tradition of associating India with effortless fertility, casting it as a source of gain 
without toil and a place where men of action became idle and developed "imperial boredom."7 India itself had therefore been portrayed through a rhetoric of excess, and by means of the nabob, its corruptive forces were imagined to be travelling to the West to infect the metropole. The creation of the nabob as a figure of satire was consequently an act of distancing the rhetorical terra firma of the metropole from the "Asiatic adventurer's" 8 realm of excess.

An examination of images that took early colonial India as their subject has revealed multifaceted networks, not merely of artistic production, but also of artistic influence. The distance between India and London, described by the first GovernorGeneral of India Warren Hastings as "what may be call'd a distance of two years,"9 combined with the East India Company's tight control over travel to and throughout the Indian subcontinent, formed a set of circumstances that required the production of India-related graphic satire to function differently from satirical printmaking in the metropole. Britons who went to India and who made contributions to the body of India-related prints often challenged the general move toward a professionalization of satirical printmaking by sending amateur works to London to be worked up by professional engravers and sold through firms like William Holland's, "of whom all the other East India Caricature may be had." 10 East India Company surveyors, draftsmen, engineers, and bureaucrats with artistic skills provided drawings and watercolours that were often redrawn by more established artists and sometimes engraved for illustrated books about India. ${ }^{11}$ Scottish artist James Wales, for example, was hired to execute two engravings for James Forbes, a retired East India Company servant who would later publish an account of his experiences in India in his Oriental Memoirs (1813). ${ }^{12}$ British artists in India who did not normally work in a satirical mode also contributed to the market for satirical prints by sending designs that could then be reworked in London. James Moffat, who worked out of Calcutta from 1789 to 1815, was a landscape artist and topographical engraver who supplemented his income by producing satires of Anglo-Indians (British colonials who spent time in India) at a time when these were becoming increasingly popular. They were then engraved and sold in the metropole, and some were revised and reissued later in the century to meet the continuing demand for India-related prints. ${ }^{13}$ The sheer number of Britons involved in the production of these prints raises the intriguing possibility that Indiarelated graphic satire may in fact have been more self-reflective than previously understood, and that the metropolitan print establishment was not simply mocking Anglo-Indian experiences, but participating in a complex series of market-driven transnational exchanges.

Indian artists may have satirized Anglo-Indians and used an existing metropolitan market to deliver resistance to the imperial project from its new subjects. A fascinating example is Scene in the East Indies, depicting a hookah-smoking nabob with his Indian servant (fig. 2). ${ }^{14}$ The hookah was a recurring motif in Indiarelated graphic satire. Having been a conventional prop in the portrait works of British artists in India such as Robert Home and Arthur William Devis, the hookah was soon relegated to humorous portrayals of Anglo-Indians. ${ }^{15}$ In this print, the servant asks whether the captain, who identifies himself as being from the 53rd (Shropshire) Regiment, will be eating at home today. 16 The captain, who has unpaid debts, is concerned that the servant will spend too much on food and sets an unrealistic limit of four rupees. Compared to the attractively rendered servant, the captain's grotesquely bulbous forehead and improbable attempt at economy suggests that Company artists-Indian artists who worked in a hybrid style when traditional patronage was supplanted by British authority—may have extended their hands to satire. ${ }^{17}$

In India-related British images, there was an inversion of the customary influence of portraiture upon caricature. To "obtain this art" of caricature, according to Francis Grose in his Rules for Drawing Caricaturas, "the student should begin to draw the human head, from one of those drawing-books where the forms and proportions, constituting beauty, according to the European idea, are laid down." 18 Grose's text illustrates how parody in the service of social comment was tied to aesthetic discourse. As Natasha Eaton's work on the rarely-studied interactions between Mughal and British regimes has demonstrated, portraiture functioned in India with a greater degree of complexity than formerly appreciated. ${ }^{19}$ To consider the impact that graphic satire seems to have had on portraiture enriches our understanding both of the function of India-inspired graphic satire and of portraiture's receptiveness to influence. Graphic satires of the nabob had such an influence in British visual culture that as a body they could transform the meaning even of an authoritative portrait by Van Dyck. Moreover, this development occurred during a time of increasing anxiety about Empire. In the following section, after exploring the social function of the figure of the nabob, I will consider Joseph Wright of Derby's Portrait of a Man, Known as the "Indian Captain" (ca. 1767; fig. 3), a painting executed at a time when apologists of empire still claimed that East India Company conquests in India had an enlightened, civilizing influence on barbarous regions of the East. ${ }^{20}$ My objective is, first, to consider how humour in the service of censure becomes in itself an excess, spilling over into earlier works which are then viewed anachronistically by beholders as amusing stabs at British men with ties to India; and second, to provide another feasible explanation for the fact that after the 1790 s, portrait subjects increasingly took on visual markers of British national or traditional poses and dress and turned away from depictions of liminal lives lived in transcultural states. ${ }^{21}$ 
The significance of the nabob, both as an embodiment of corruption and as a subject of graphic satire, is that he had the ability to inhabit multiple and contradictory spaces. For example, though he was British, venturing to India made him AngloIndian. Returning home somehow meant he was invading Britain: a 1785 article in The Times described the many "new-imported Nabobs, who have a vast deal of money among them."22 In this sense, the nabob was both a domestic product and a foreign import infiltrating what was touted as a moral, domestic market, and he reinforced eighteenth-century anxiety about the threat of excess from the over-importation of foreign wares. ${ }^{23}$ The nabob's liminality—anthropologist Victor Turner uses the term to describe the condition "betwixt and between established states of politico-jural structure"24_suggests a permeability of the conceptual borders defining him. This premise benefits considerably from the theoretical foundations laid by scholars who recognize significant porosity at the boundaries of identity, particularly at those margins delineated by empire. ${ }^{25}$ In essence, in a metropole in the process of fashioning a national identity, the nabob embodied imperial anxiety. ${ }^{26}$ The nabob could therefore be described as both a product of, and a reaction to, uncertainty in an emerging debate regarding national distinctiveness. Anglo-Indians, according to Jitender Gill, were colonials who "come to/from" India; this back-and-forth quality of the nabob also implies marginality. ${ }^{27}$ As the anthropologist Mary Douglas explains, danger lies in the transitional states inhabited by marginal beings and the individual who passes from one state to another is not merely a danger to himself, but a menace to the blameless inhabitants of the interior. ${ }^{28}$ The perception of the nabob's transitional status helps to illuminate why he was so reviled in eighteenth-century Britain.

Among portraits produced between the late 1760s and the 1790 s, there are examples in which the sitter identifies with the East through India-inspired apparel, exotic flora and fauna, Indian servants and companions, and references to famous Indian landmarks. ${ }^{29}$ In Joshua Reynolds' portrait of Captain John Foote (ca. 1761; fig. 4), for instance, the sitter is splendid in Mughal dress. ${ }^{30}$ In the last decade of the eighteenth century, however, British men with interests in India deliberately reinforced their Britishness by emphasizing European dress in settings devoid of landscape, and made reference to an India of administrative dependence, a setting for the exercise of military or commercial prowess. A key example of this is the portrait of John Mowbray attributed to Irish painter Thomas Hickey (ca. 1790; fig. 5). Although Mowbray was an East India Company civil servant, this portrait emphasizes his activities in private trade with the firm of Mowbray, Graham and Skirrow of Calcutta. He is shown amidst piles of important papers, flanked by a messenger, while Mowbray's banyan - a Hindu trader retained to assist in private trade-delivers an update from the commercial ledger. ${ }^{31}$
Mowbray's knee-length stockings and dark European-cut suit with ruffled cravat and embroidered waistcoat stand in stark contrast to the dress of his Indian counterparts. The painting emphasizes the distinctions between powdered wigs, turbans, and head wraps, and, with the exception of the map of the areas of Bihar and Tibet, the furnishings could be found in a London office. ${ }^{32}$ While certainly engaged with his banyan, Mowbray has an air of casual power. Mildred Archer, Hermione de Almeida, George H. Gilpin, and Beth Fowkes Tobin have rightly argued that the minimizing of Indian settings and the exoticizing of native subjects in such portraiture reflected increased colonial

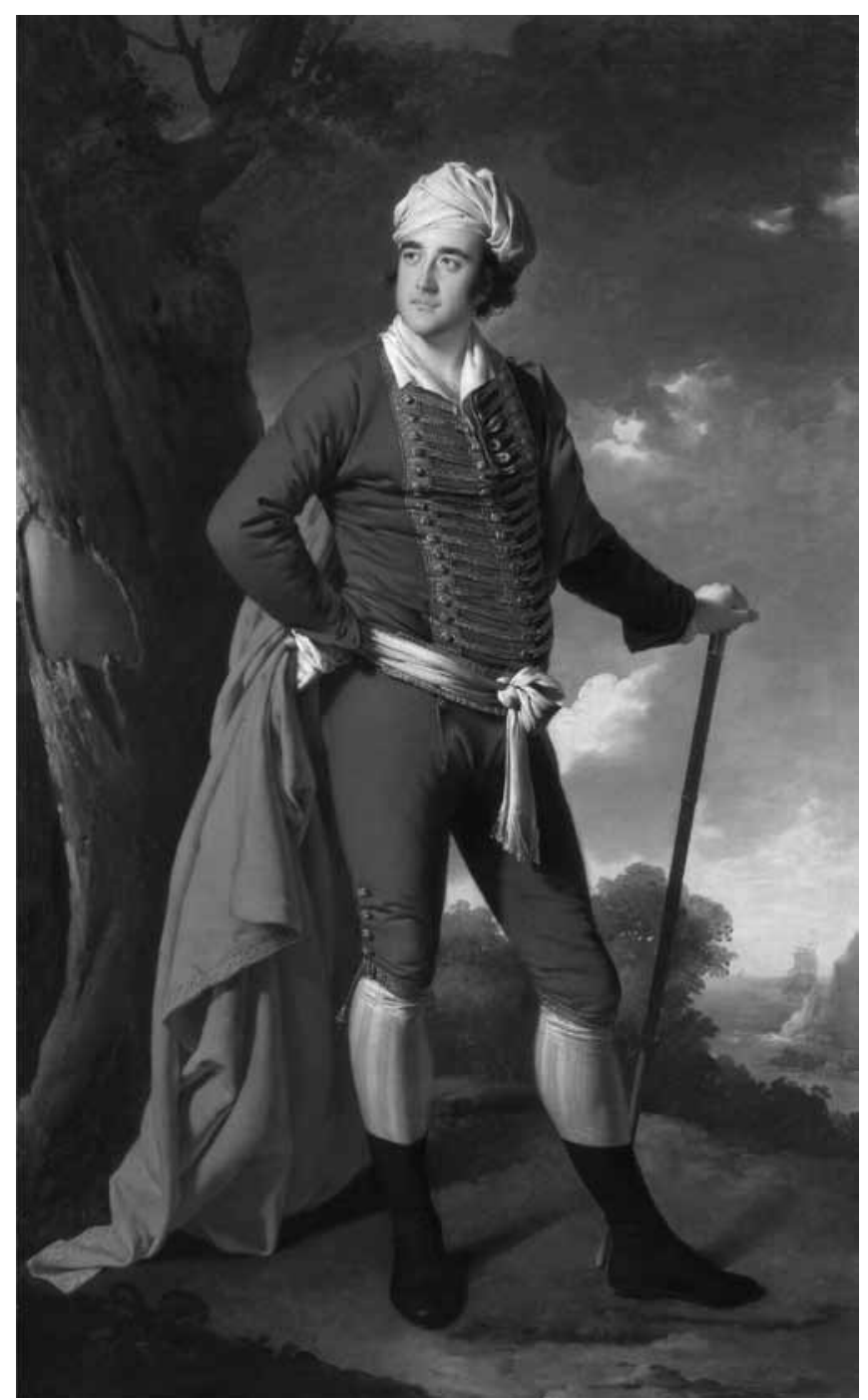

Figure 3. Joseph Wright of Derby, Portrait of a Man, Known as the "Indian Captain", ca. 1767. Oil on canvas, $236.2 \times 138.4 \mathrm{~cm}$ (Photo: Yale Center for British Art, Paul Mellon Collection B1981.25.713). 


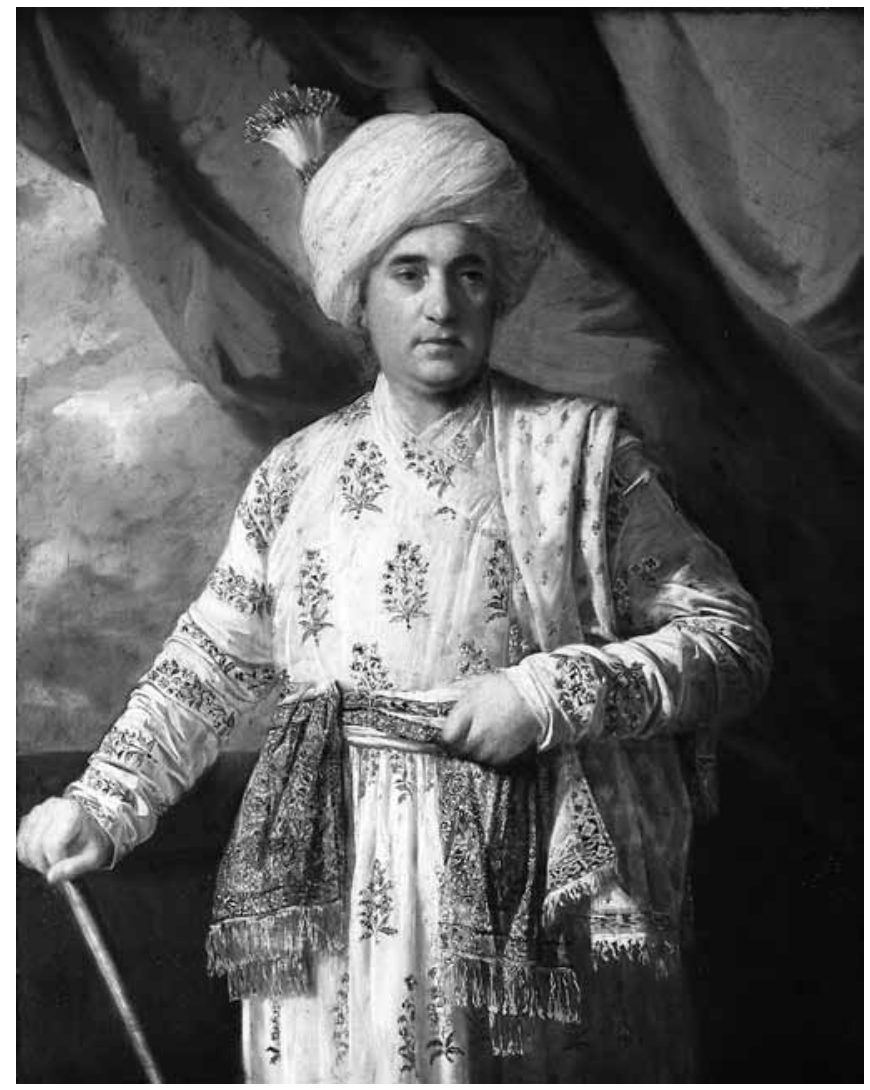

Figure 4. Sir Joshua Reynolds, PRA, Captain John Foote, 1761. Oil on canvas, $123.2 \times 99 \mathrm{~cm}$ (Photo: (C) York Museums Trust (York Art Gallery), UK/ The Bridgeman Art Library).

confidence and imperial domination. ${ }^{33}$ It is clear that Hickey's portrait commemorates the pursuit of fortune by a man who is unquestionably British, a subject who benefits from rich Indian resources but remains dissociated from them. The distancing manifest in this type of portraiture suggests a response to the effects of graphic satire, a medium that could address more directly the mounting anxieties regarding empire.

One of the first examples of graphic satire that referenced nabobs was The Genius of the London Magazine Unmasking the Times (1772), where a winged goddess exposes the real face of The Times, a dark, seated creature who recoils from the light. ${ }^{34}$ Inscribed strips of paper unfurl from a box and out of his pocket, one of which reads "Nabobships." This notion, that the character of nabobbery would be revealed through representation, offers a vital clue to the tensions between portraiture and graphic satire vis-à-vis India at the close of the eighteenth century. 35 The depiction of nabobs in satirical prints was an act of criticism deployed in a period when Britain's colonial projects were in a state of confusion: the supposedly secure and clearly much

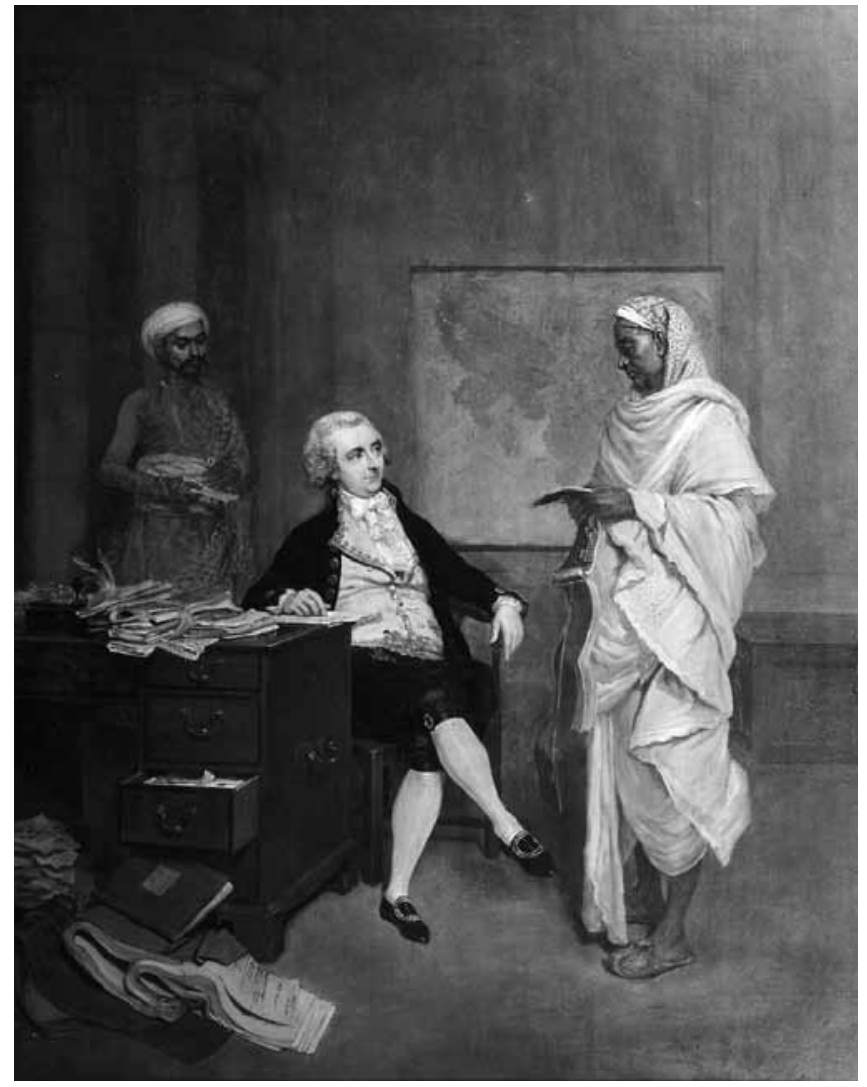

Figure 5. Attributed to Thomas Hickey, John Mowbray and His Money Agent and an Indian Messenger, ca. 1790. Oil on canvas, $104 \times 81 \mathrm{~cm}$ (Photo: The British Library Board, Shelfmark F638).

desired North American territories had wrested independence from England; West Indies plantations still depended on slave labour, illegal in the metropole since 1772; and the unplanned empire in India was burgeoning without clearly defined, or agreed upon, objectives. ${ }^{36}$ In this political climate nabobs were perceived as members of an upstart class, "Asiatic plunderers" 37 who threatened the political, social, and economic status quo in Britain, 38 even though reports of financial success in India were exaggerated and the Company's servants had staggering rates of mortality. 39 Eighteenth-century representations of nabobs in graphic satire also point up a more objectionable reality. The debt accrued by would-be nabobs in India threatened to undermine the colonial enterprise, not because of the moral turpitude, financial mismanagement, or lack of resources that debt implied, but, rather, because a subjugated group-Indian financiers-could gain power in this way. 40

Even allowing for the tensions between the real and the imagined in the figure of the nabob, the suppleness of nabob imagery in graphic satire was remarkable. To be represented as 
a nabob, one need not be an Anglo-Indian pursuing a fortune in India. James Gillray's Dun-Shaw, one Foot in Leadenhall St. and the other in the Province of Bengal, published 7 March 1788 (fig. 6), depicts the British politician Henry Dundas, First Viscount Melville, as a colossus clad in a kilt and slapdash turban straddling the ocean between Company headquarters in London and the roof of India House in Bengal. ${ }^{41}$ Satirical representations of nabobs in this period often utilized preexisting upstart iconography that immediately identified the subject as socially or politically presumptuous. 42 The visual emblem of the colossus symbolized unmerited pride followed by inevitable downfall. Gillray goes further in depicting the Viscount as an Eastern despot, a problematic figure for a nation attempting to reconcile what it meant to be "a free though conquering people." 43

In spite of the focus on men who are portrayed as inhabiting the fringes of society, politics, or empire, caricature and portraiture appear to be at the core of identity politics in the late eighteenth century. It is therefore more than worthwhile to unpack the tensions between portraiture and caricature with respect to India in this period.

In the catalogue of the 1767 Society of Artists exhibition in London, Joseph Wright of Derby's Indian Captain is listed as "Portrait of a gentleman, whole length" 44 (fig. 3). The painting depicts a man in a green military-inspired suit and flowing red cape, posed confidently in a wooded landscape overlooking a bay. It is quite likely a boast of his martial and shipping connections. The white turban suggests that the sitter's professional associations were created in India, a conclusion shared by a glowing review of the portrait published in Le Pour et le Contre (1767) which predicted that "Orrery *Wright shall there the test abide, / In high historic stile, and epic pride; / His Indian Captain makes the Critics stare, / And awes their envy with his martial air." 45 The portrait is fanciful and mysterious. Military historians would be quick to point out that the uniform of the Indian Captain bears no relation to the blue and red uniforms of the East India Company in this period. 46 An initial identification of the sitter as philanthropist, essayist, and poet Thomas Day was abandoned in the 1980s following comparisons with other portraits of Day. According to Benedict Nicolson, the departure from military accuracy may be explained by Wright's 1760s experimentation with fancy dress portraits, possibly to demonstrate his virtuosity to exhibition critics and potential patrons, some of whom may have been returning AngloIndians keen to commemorate an experience abroad and the source of their newly-found wealth. ${ }^{47}$ Wright also painted a bust-length portrait of the same sitter with a similarly embroidered uniform, a plum-coloured fur-lined coat and, significantly, a turban. 48
A convention of representing men wearing turban-like headdresses existed in British portraiture throughout the eighteenth century. This was often part of a trend toward informal, interior portraits depicting the sitters in private dress and recalling representations of great thinkers at work. 49 An earlier example is Sir Godfrey Kneller's 1717 portrait of bookseller and publisher Jacob Tonson, shown holding a copy of his most successful publication, John Milton's Paradise Lost. 50 The informal portrayal of Tonson wearing a turban not only makes reference to the intended audience of the painting, namely, his private dining club, where such informality was expected, but also suggests that the sitter may have identified more with the intellectual act of writing than with publishing. Another source of the use of the turban was the adoption of the "Turkish Style" for

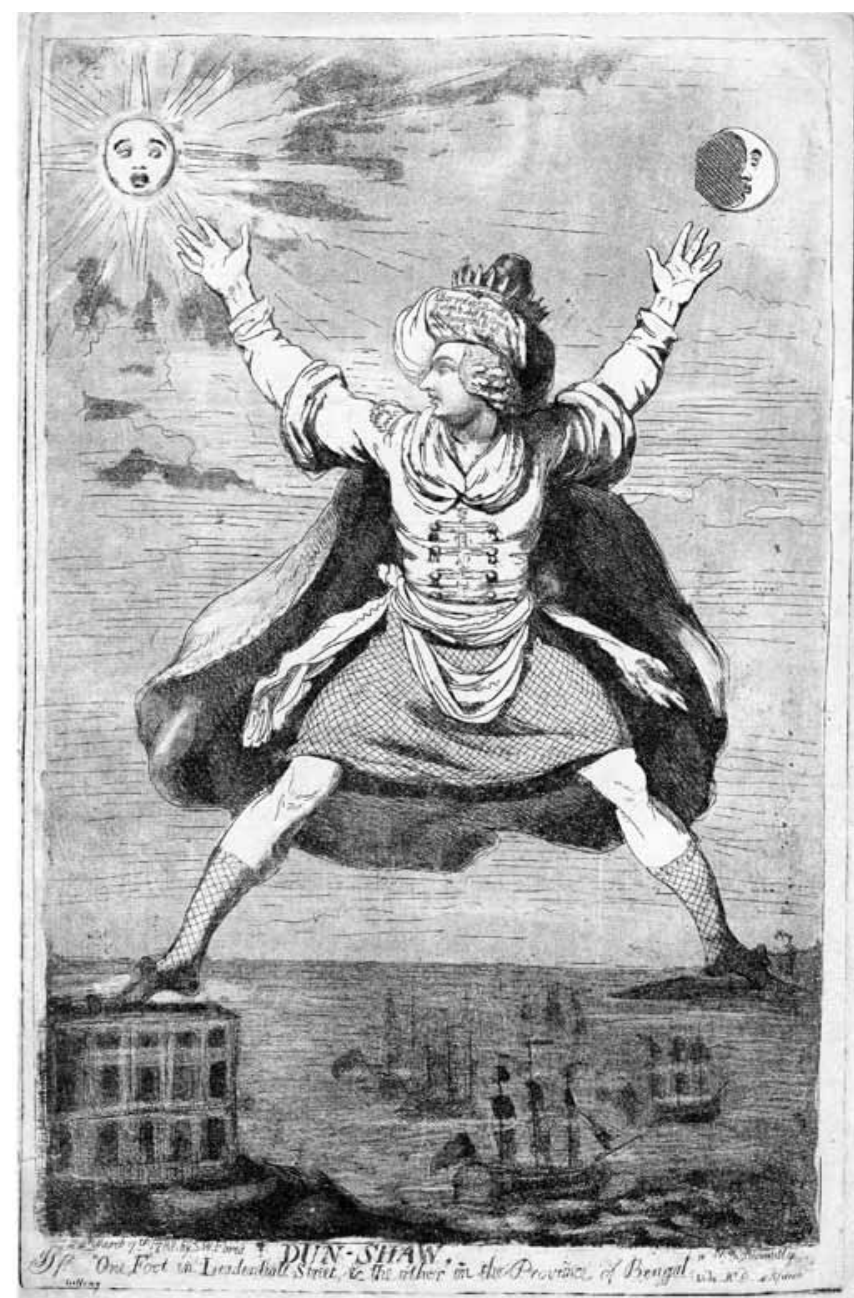

Figure 6. James Gillray, Dun-Shaw, one Foot in Leadenhall St. and the other in the Province of Bengal, 7 March 1788. Etching, $41.7 \times 27.4 \mathrm{~cm}$, London, British Museum (Photo: (C) Trustees of the British Museum). 


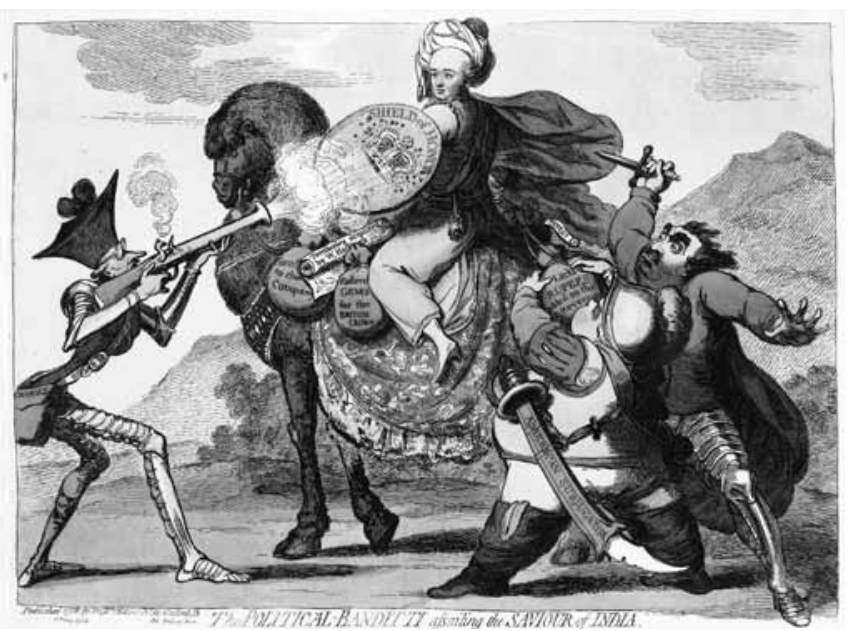

Figure 7. James Gillray, The Political-Banditti Assailing the Saviour of India, II May 1786. Hand-coloured etching, $28.89 \times 40.64 \mathrm{~cm}$. London, British Museum (Photo: (C) Trustees of the British Museum).

British portraits, possibly influenced by the seventeenth-century Dutch vogue for Persian dress, a trend influential enough to affect both portraiture and religious painting. According to art historian Herman Goetz, the "bizarrerie" of Persian fancy dress found a welcome home among European absolutists in Baroque Europe as they became interested in Eastern despots, resulting in the custom of sitting for a portrait "costumed as an Oriental nobleman." 51 In the eighteenth century the Turkish Style was also often seen in the portraiture of British and American women, a fashion that continued well into the nineteenth century, when turban-like headdresses were "universally adopted" and frequently adorned with pearls, lace, or ostrich feathers. 52 Lady Mary Wortley Montagu's repeated use of the turban in her portraits not only referenced her life in Constantinople as wife to the British Ambassador to Turkey, but also signified her intellectual engagement with the East. 53 Turbanlike headdresses continued to appear throughout Regency portraiture, exemplified by Sir Thomas Lawrence's portrait of Mrs. Jens Wolff, a friend and possible lover of the artist. ${ }^{54}$

The Indian Captain cannot be easily reconciled with either the Turkish Style or, given the sitter's formal, if imaginative, dress, the informal portrait tradition. The military-like uniform and the three-masted ship in the distant bay point not to an historical, fashionable, or intellectual engagement with the East, but rather to the exercise of martial and mercantile prowess in India more fitting with the exploits of the East India Company. Since the Renaissance, the turban had also been viewed in England as the "preeminent symbol" of Muslim authority. 55 The most compelling evidence that this is, indeed, a portrait of a man connected to India is that the execution of the painting and the critic's subsequent designation of and praise for the work predates caricatures of nabobs in graphic satire; the sitter could still expect to be taken seriously in his turban.

Even so, there is evidence at this time that sartorial homages to India by Company men in London were beginning to be reflected upon comically. We read in the "Account of the King of Denmark's Masked Ball” (1768) that

\begin{abstract}
Many of the most superb, as well as the best-fancied dresses in the whole assembly, were those of eminent citizens, or those who had acquired their fortunes by trade. On this occasion the quantity of gold and silver tissue made into Indian, Persian, and Chinese habits, together with the quantity of diamonds, with which these habits were decorated, is past belief. Nothing but the actual view could convince the mind of its reality. Lord Clive represented an Indian Nabob. 56
\end{abstract}

The various descriptions of Eastern dress in magazines and novels are examples of the laying out of the excesses of Eastern rulers for British audiences. In an excerpt from Zulima: An Oriental Tale (1764), for instance, the author creates a literary representation of a figure whose "dress was purple enriched with gold, and the jewels in his turban glittered like the rays of the sun.... Yet in the midst of his riches Hamed was temperate; fifty women only had he in his Harem." 57 Turbans, in particular, were being associated with foolishness. The following passage from "A Description of the Curious Boat, Lately Brought from India, and Presented to Their Majesties by Gov. Vansittart" (1768) describes one officer's exotic job on the boat:

Such an officer as is here mentioned, is at this day actually employed in most of the row-gallies in the East Indies, particularly gallies of state-as is the vessel we are now describing-his province is to make the rowers cheerful. He is dressed in a fantastic habit with feathers in his turban and bells on his arms and legs, assuming a character not unlike our Merry Andrew, and is known by the name of the fool of the boat. 58

Nabob imagery employed generic figures to articulate the broadly negative consequences of empire building, but artists also produced scathing political commentary that responded to specific India-related political affairs and featured major, recognizable figures. The frequency of this form of nabob imaging can be correlated to three main events in the late eighteenth century: the 1770s Parliamentary Inquiry on the East India Company, which examined the Company's alleged mismanagement of financial assets; the formulation of the India Bills between 1780 and 1785, centralizing British rule in India with a Board of Control; and the impeachment trial of Warren 
Hastings (1788-95). 59 Hastings, the first Governor-General of Bengal (1773-85), is the figure most frequently lampooned as a nabob through the satirical device of dressing him in exaggerated Indian costume. Gillray's The Political-Banditti Assailing the Saviour of India (fig. 7), 60 for example, questions the legal strategy of portraying Hastings as an honourable and effective administrator: Gillray depicts him in Eastern garb, while his detractors are cast in the role of banditti, figures closely associated with the immoral habits of the East. ${ }^{61}$ Gillray and other graphic satirists invented and referred to sartorial excesses by Company servants by repeatedly depicting Hastings in an oversized jewelled turban and Indian dress. An intriguing literary example closely illustrates the tensions between likeness and caricature in such works: in her chapter "On Taste" from The Female Mentor: Or, Select Conversations (1793), Honoria, the author, reflects on the "highly ridiculous" appearance of the "Nabob's lady;" yet, in a moment of astute self-reflection, she recollects metropolitan fashions "which were no less preposterous."62 Honoria's remark that "the caricature prints...scarcely exceed the reality," illustrates how graphic satire functioned, not solely as a document of imperial anxiety, but also as a dynamic participant in a dialogue of representation. 63
There is one more way of looking at the Indian Captain that may be fruitful. According to David Kunzle, in the period immediately following the Napoleonic Wars, caricaturists viewed officers of the armed services in two ways: "as idle fops and as impoverished heroes." 64 This binary is captured much earlier in The Unhappy Contrast by an unknown hand, where a soldier from the King's Army and an East India Company captain compare the ways they have been rewarded for their loyalty (fig. 8). Skinny, missing limbs, and steps away from the King's Bench prison, the King's Army soldier is barely subsisting on half-pay, and his honour is being compared to a tattered "custom house oath," a proverbial expression for something of little consequence. The status of the East India Company captain is, in contrast, elevated; he stands on, and is surrounded by, rewards-cups, saucers, chamber pots, fine military gunpowder, tea, silks, muslins, napkins, shawls, and bags of money. ${ }^{65} \mathrm{He}$ is over-fed and under-exercised, a testament to the idleness of life for the British in India at the expense not only of honour, but also of national interests. ${ }^{66}$ The rotundity of the nabob's belly is also emphasized in an anonymous print from 1781 entitled The Scourge of India Captains taking his usual Regale. 67 The subject is isolated in the composition and set in profile. His round

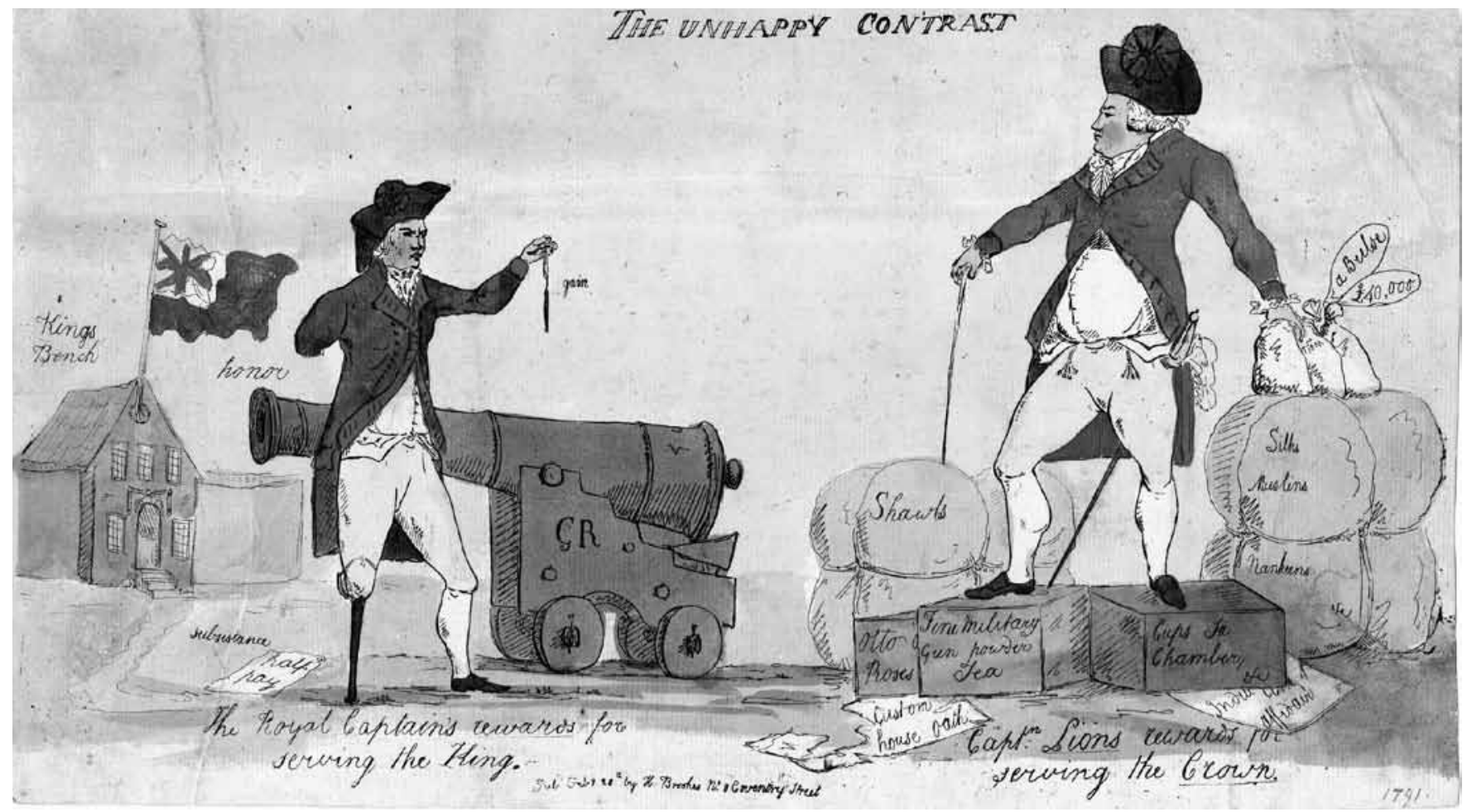

Figure 8. Anonymous, The Unhappy Contrast, ca. 1791. Hand-coloured etching, $20.3 \times 36.3 \mathrm{~cm}$. London, British Museum (Photo: () Trustees of the British Museum) 


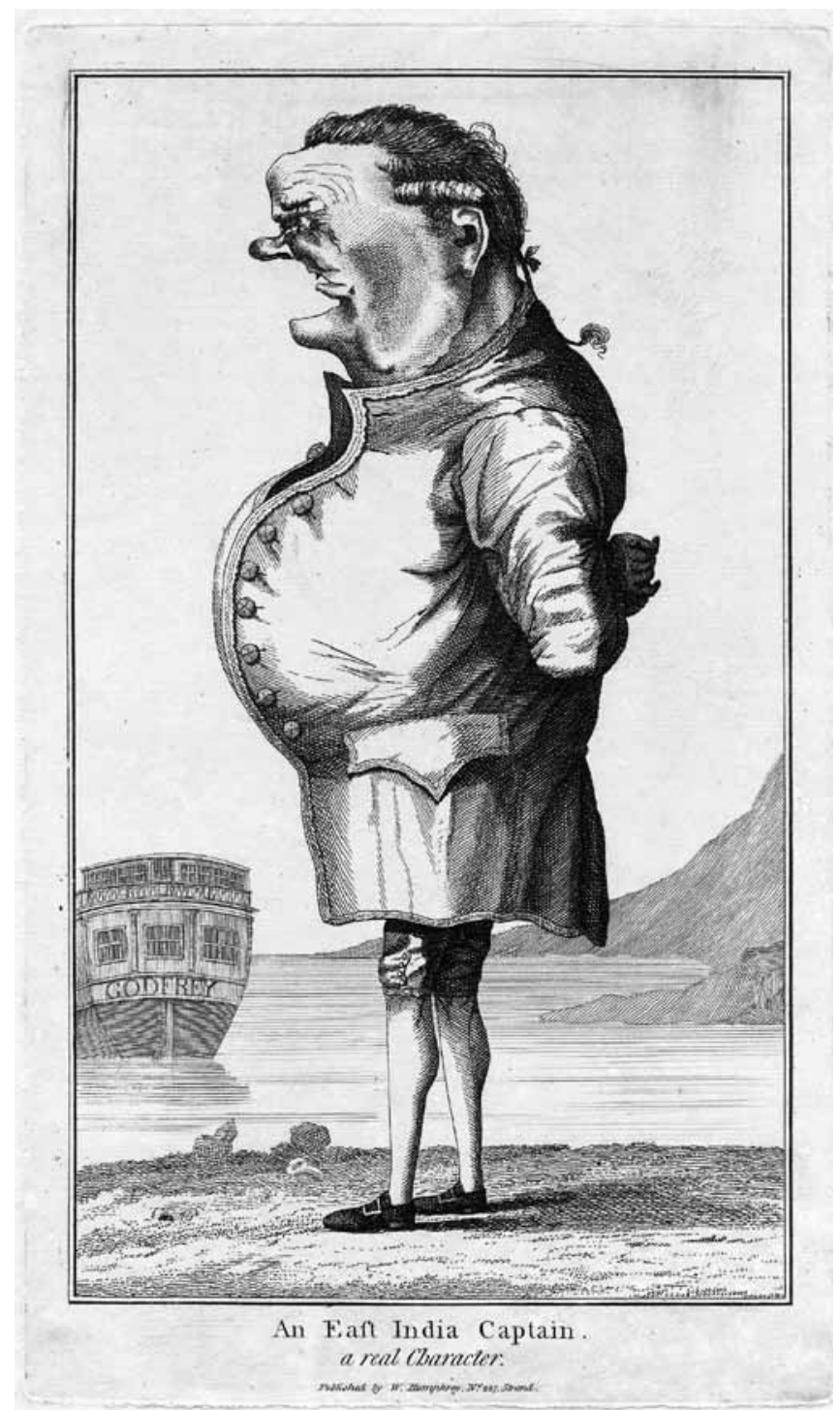

Figure 9. Anonymous, An East India Captain. A Real Character, undated. Etching, $27.6 \times 16.2 \mathrm{~cm}$. London, British Museum (Photo: (C) Trustees of the British Museum).

stomach spills into and becomes part of the tankard he rests on his thigh. Whether the title refers to the ship he commands or to the captain himself, it is difficult to believe that this unfit, aleimbibing figure of excess could be a terrible conquering force. An East India Captain. A Real Character by an unknown hand takes the corpulent quality of the nabob to a grotesque extreme (fig. 9). ${ }^{68}$ Here, the nabob's underdeveloped sea legs have little hope of supporting his body, and his bulbous forehead and alcoholic blush suggest he is a thick-headed figure of habitual ex-

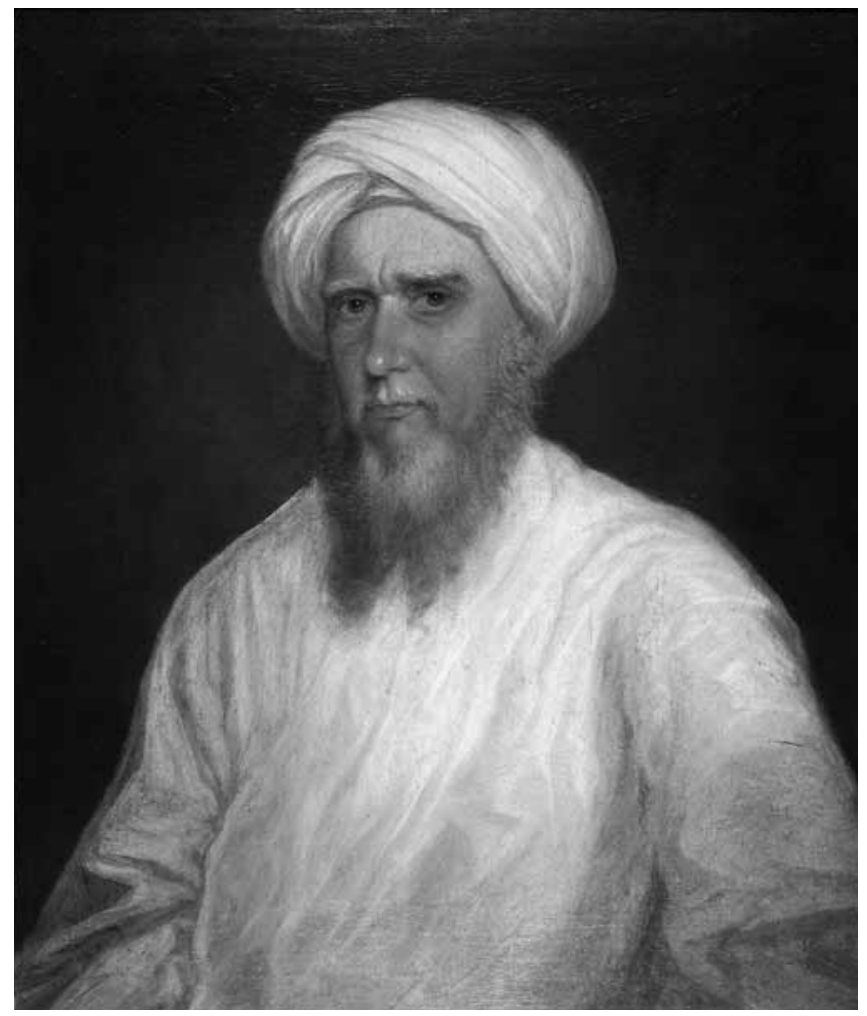

Figure 10. James Wales, Hugh Seton, 1793. Oil on canvas (Photo: The British Library Board, Shelfmark F637).

cess. Crucially, the idleness signified by the portly nabob not only references the often-addressed phenomenon of the nabob employing many servants to do even the simplest task in India, but also suggests an alarming lack of industriousness, one of the main tenets by which the British justified their imperial entitlement. ${ }^{69}$ Through their idleness, nabobs challenged British claims of cultural superiority based on industriousness, disturbing the imagined national character. In this light, the plump curve in Wright's Indian Captain appears significant, and it is quite difficult to observe the captain's self-assured pose without a sense of irony.

If the excessive nature of caricatures of East India Company men-as turbaned, corpulent, bulbous-headed, or simply confidently-posed with a walking stick-could influence subsequent receptions of earlier paintings, a mutual influence between portraiture and caricature does not seem astonishing. European traders in India frequently wore flamboyant local attire when they attended private and public affairs; yet an emblematic divergence exists between the reality of conducting a life in India and the commemoration of those lives in commis- 


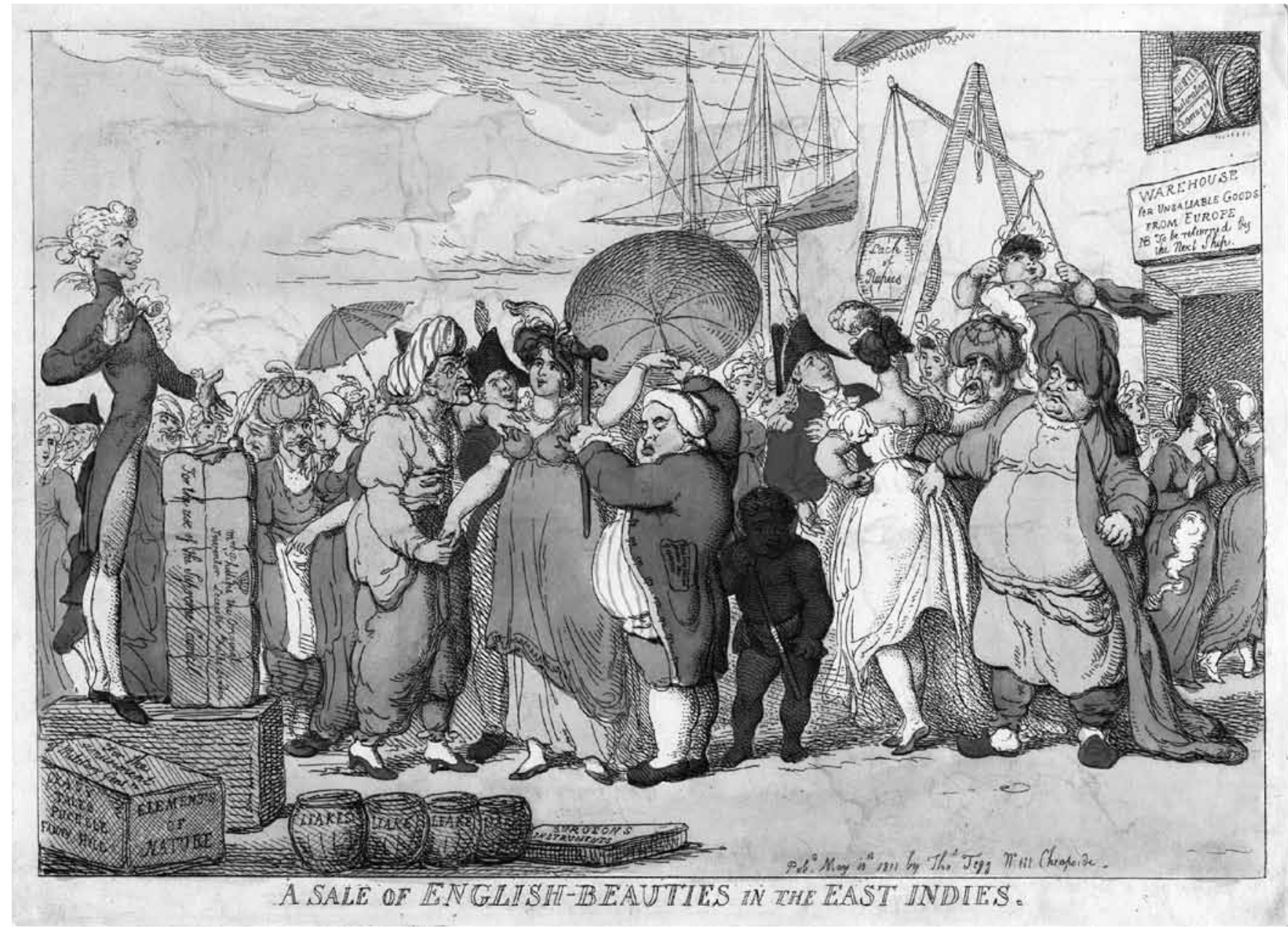

Figure II. Thomas Rowlandson after James Gillray. A Sale of English Beauties in the East Indies, I8II. Etching and aquatint with added watercolour, $43 \times 55 \mathrm{~cm}$, New Haven, The Lewis Walpole Library, Yale University (Photo: Courtesy of The Lewis Walpole Library).

sioned portraiture. 70 This tension is in part explained by the theoretical debate which sets "the genuine habits of nature" in opposition to "those adventitious, those affected and forced airs" of fashion, to use Sir Joshua Reynolds's words. ${ }^{71}$ The term "adventitious" seems particularly well-suited to Wright's Indian Captain. Although it represents "the genuine habits of nature," James Wales's portrait of Hugh Seton (1793) would fare no better with subsequent historians (fig. 10). It is not fashion, commemoration, nor fancy which has Seton "in the guise of a Mahomedan," as he was described in a contemporary account. 72 Rather, it seems to be that this is what he was wearing when he sat for the portrait. The sitter has been identified as "unbalanced" and the portrait is now seen as a curious testament to his eccentricity. ${ }^{73}$ Seton left Britain in 1786, dishonoured after incarceration for debt, and wandered through the East until his death in 1795. His letters to his son Archibald, also in India, portray him as a compulsive peripatetic. ${ }^{74}$ This bustlength portrait shows a stern man emerging from a dark background, with a long, unkempt beard, tanned face, and troubled brow. A biographical approach to this likeness would lead us to the conclusion that this is not a portrait commemorating the riches of the East with splendid fabrics and jewelled turbans, but a sober depiction of a liminal man, not only on the edge of empire but also, driven by debt and disgrace, on the brink of insanity.

In caricatures of the nabob, "Female adventurers" were also pilloried, often as unsavoury commodity imports, as exemplified by Gillray's 1786 A Sale of English-Beauties in the East In- 
dies. 75 On a dock in Calcutta a foppish auctioneer oversees the inspection of a new cargo of British women by a throng of potential customers. Dorothy George and Draper Hill have argued that the crowd consisted of both British and Indian men. ${ }^{76}$ In this instance, the argument seems plausible, but their conclusions cannot be extended to Thomas Rowlandson's reworking of the image for Tegg's Caricature Warehouse in 1811 (fig. 11). Skin tone was increasingly being employed to racialize people in India, and the abundance of pink faces in Rowlandson's version could be an indication that the men are nabobs. 77 This position is supported by the lack of contrast between the skin tones of prospective customers in the print, a lack of distinction made even more powerful when compared to the diminutive, darkskinned servant holding an umbrella over a central figure. ${ }^{78}$ By altering the image, Rowlandson emphasized the nabobs' cultural cross-dressing, an activity which was becoming increasingly suspect. His modification also suggests that the idea of native men and Anglo-Indians competing for British women had become taboo.

John Russell's portrait of Mrs. Elizabeth Sophia Plowden and her Children (1797), an intriguing and rare portrayal of a British woman in Indian garb, further complicates the relationship between sitters and Indian dress. ${ }^{79}$ This portrait probably commemorates Plowden being granted the honourary title of Begum, a lady of high rank in India, by the Mughal Emperor Shah Alam in 1788.80 Nevertheless, I am hesitant to speculate further along these lines, since, in a letter to her sister Lucy, she describes a recent masquerade at Fort William: "I think an account of the Character I was in may entertain you.... I had long had this idea that of [sic] an Indostani or Cashmiri Singer would make an excellent group at masquerade." 81 Plowden clearly thought of the ensembles she donned as costume, not clothing. Douglas Fordham's recent identification of costume as a central issue in attempts by British artists to reconcile metropolitan aesthetics with the diplomatic needs of the Maratha court of Poona in the 1790s explains how sartorial details were often at odds with Western artistic principles. "At stake was whether an appropriate balance between neoclassical ideals and imperial contingencies could be struck, as well as the more troubling question of whether they should share the same pictorial frame." 82 A British man or woman wearing Indian garb, a conflation of emerging national identities and colonial realities, could complicate the endeavour to distance the metropole, not solely from the nabob, a liminal figure cast as an agent of corruption, but from Indians too. The notion of costume was therefore a convenient filter by which sitters could distance themselves from India, even while being presented in Indian dress. If a sitter approached Indian garb as a costume, then by definition the sitter embraced parody.
As the attempts for clear distinctions between "the Briton" and "the Indian" began to succeed on an administrative level when the British government gained better control of the East India Company and the Company of its representatives, the absorbent figure of the nabob became part of an inelegant past and fell into decline. In 1840, Thomas Babington Macaulay wrote that if "any of our readers will take the trouble to search in the dusty recesses of circulating libraries for some novel published sixty years ago, the chance is that the villain or sub-villain of the story will prove to be a savage old Nabob." 83 The implication was that the constructed character of the nabob was no longer a threat, and could slowly end his days as a mild figure of folly. William Makepeace Thackeray's character Jos Sedley from Vanity Fair (1848) — gluttonous and arrogant, yet timid when confronted with opportunities for valour (or the woman he desired) - shows how the nabob had been undone as a threat to the metropole. ${ }^{84}$ However, although his character was weak, Sedley's wealth, achieved through tax collecting in India, made him respectable, and ultimately he became a sympathetic figure preyed upon by an overly-industrious woman, signalling that the metropole now had bigger problems than social-climbing nabobs. This can be seen in an anonymous image simply entitled Nabobs, published by Holland in 1811 (fig. 12). While at first glance it seems to evoke the illustrations of animal and human profiles such as those made by the comparative anatomist Petrus Camper, Nabobs actually demonstrates a resounding lack of those menacing qualities that had at one time defined nabobs. The urge to distance nabobs from Britain, which had in the past been achieved through markers of Eastern excess, is now thwarted by the satirist's emphasis on the ubiquitousness of these figures (and perhaps their interest in hair styles). Significantly, even the representation of nabobs in graphic satire has moved from the periphery of the imperial project into the centre of the metropole, to be counted among many other metropolitan subjects of ridicule. Thus, over time, the colonial project eradicated the liminal figure who could assume the characteristics of the East. In his place was a strong British body that resisted Eastern excess. Figures who had adopted the attitudes and the trappings of the East were made to seem peculiar, while figures predating the anxieties concerning an Eastern empire as expressed through graphic satire, became open to anachronistic ambivalence. 85 These anomalies were banished to Macaulay's "dusty recesses" of pre-colonial histories and in their place emerged portraits such as An Officer in the East India Uniform of the 74th (Highland) Regiment (ca. 1796) by John Opie. In this painting, Opie depicts an heroic agent of empire, dressed in accurate military uniform, who celebrates his military prowess in India. 86 Before this banishment, however, graphic satire had influenced the way in which the British represented themselves for their contemporaries and for posterity. 


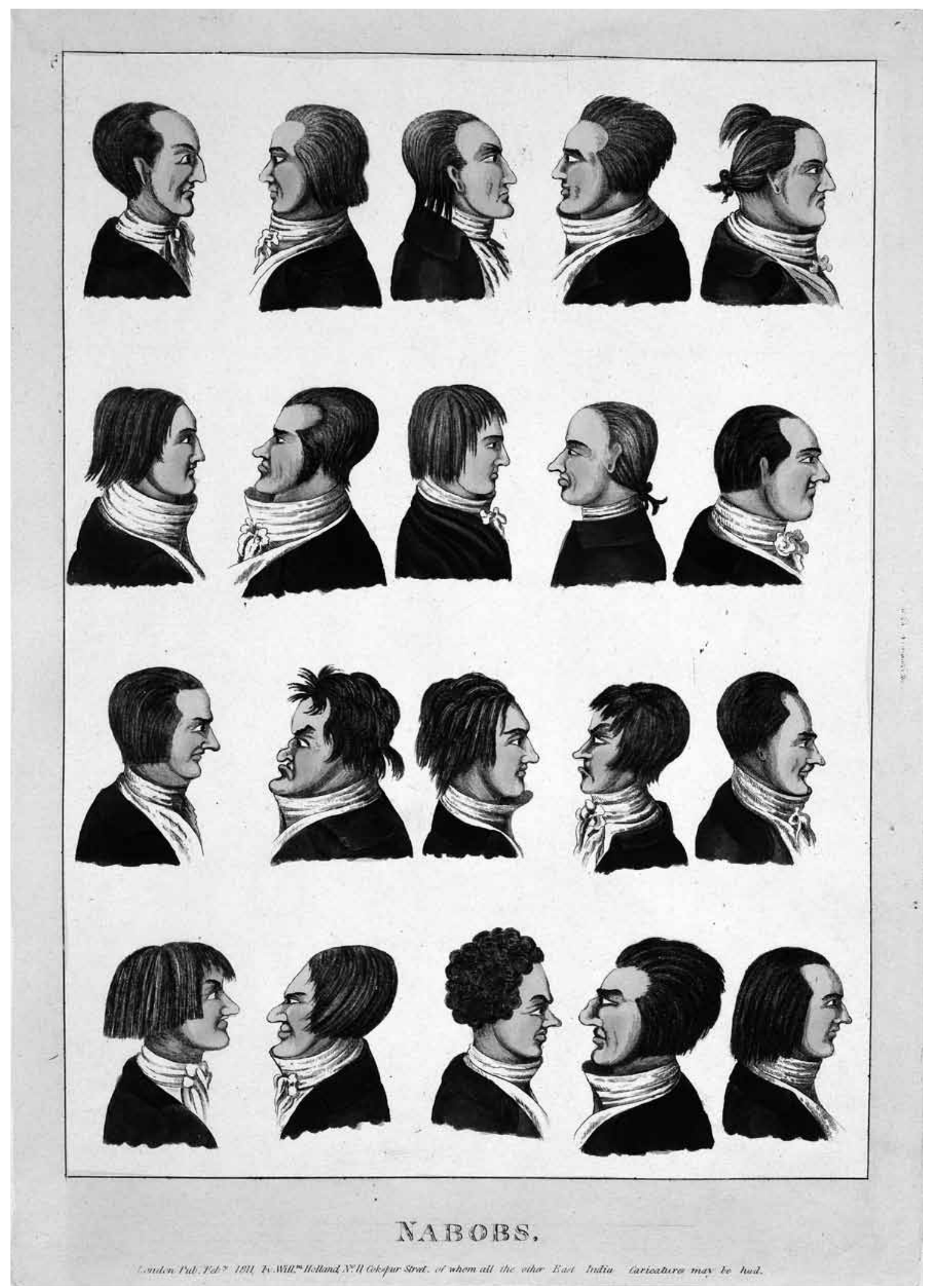

Figure 12. Anonymous, Nabobs, 1811. Coloured etching with aquatint, Washington D.C., The Library of Congress (Photo: Library of Congress, Prints and Photographs Division, LC-USZC4-13687). 
Notes

1 This bird has been identified as a green-winged macaw, a species native to northern and central South America and not India. Bruce Boehrer, “'Men, Monkeys, Lap-Dogs, Parrots, Perish All!': Psittacine Articulacy in Early Modern Writing," Modern Language Quarterly 59, 2 (June 1998), 175; Christopher Alan A. Bayly, ed. The Raj: India and the British, 1600-1947 (London, 1990), 73.

2 James M. Holzman, The Nabobs in England: A Study of the Returned Anglo-Indian, 1760-1785 (New York, 1926), 7-8. William Feilding, First Earl of Denbigh may have helped to create this idea of the nabob, for when he returned to in England in 1633, he was laden with jewels. Andrew Thrush, "Feilding, William, first earl of Denbigh (c. 1587-1643)," Oxford Dictionary of National Biography (Oxford, 2004), online ed., Jan. 2008 [http://www.oxforddnb.com/view/article/9251, accessed 29 April 2011].

3 James Peller Malcolm, An Historical Sketch of the Art of Caricaturing (London, 1813), 10. For a discussion of the general functions of graphic satire, see Sheila O'Connell, The Popular Print in England 1550-1850 (London, 1999), 10.

4 A.T., "The Complaint of a Country Gentleman Against a Nabob," Weekly Magazine, or, Edinburgh Amusement 8 (14 June 1770), 335.

5 The Lounger 17 (1785), 162. "Inventory of James Bonwhich, deceased 30 August 1774," Bengal Inventories 14 (1774), as quoted in Percival Spear, The Nabobs: A Study of the Social Life of the English in Eighteenth-Century India (London, 1963), 183.

6 Anti-Nabob, "To the Printer of the Town and Country Magazine," Town and Country Magazine, or, Universal Repository of Knowledge, Instruction, and Entertainment 3 (January 1771), 28.

7 Pramod K. Nayar, "Marvelous Excesses: English Travel Writing and India, 1608-1727," Journal of British Studies 44 (2005), 22021; Robert Orme, Historical Fragments of the Mogul Empire [1804], ed. J.P. Guha (New Delhi, 1974), 262; Jeffrey A. Auerbach, "Imperial Boredom,” Common Knowledge 11, 2 (2005), 283-305.

8 The Times (28 February 1787), 2.

9 In Hastings's evidence to the House of Commons in 1767, as quoted in Peter James Marshall, Problems of Empire: Britain and India 1757-1813, ed. G.R. Elton, III, Historical Problems: Studies and Documents (London and New York, 1968), 29.

10 Publication line of Nabobs; see fig. 12. Other firms include those owned by Rudolf Ackermann, Thomas Tegg, Samuel William Fores, H. Brookes, and Hannah Humphries.

11 For a discussion of amateur artists in India see Pratapaditya Pal and Vidya Dehejia, From Merchants to Emperors: British Artists and India, 1757-1930 (Ithaca and London, 1986), 13.

12 Mildred Archer, "James Wales: Portrait Painter in Bombay and Poona, 1791-95," Journal of The Indian Society of Oriental Art, New Series 8 (1977), 64.

13 Though his satirical works are only vaguely mentioned, what little is known about James Moffat's life is well outlined in Hermione de Almeida and George H. Gilpin, Indian Renaissance: British Romantic Art and the Prospect of India (London, 2005), 249-53.

14 This theme was also treated by James Moffat in A Scene in the Writer's Building (1797; a later iteration of the image was published in 1813); in Thomas Rowlandson's Miseries of the First of the Month (1816); and in Charles D'Oyly's Tom Raw Forwarded to Headquarters (1828).

15 The fussy activity required a servant to pack the tobacco, fan the flames, and add more smoking material when required. Hookahburdars, specifically trained to start and maintain a good smoke, had been known to add thorn-apple and other altering substances to the pipe, resulting in unplanned delirium. A hookah smoker perilously placed himself at the mercy of an allegedly subjugated servant. Elizabeth Collingham, Imperial Bodies: The Physical Experience of the Raj, c. 1800-1947 (New York, 2006), 31. Thornapple, also called dattora or datura, was used by thieves to disable their victims. Terence R. Blackburn, Tales From British India (New Delhi, 2009), xi. For a discussion of the ubiquitous quality of hookah smoking amongst British men in India see Richard Leppert, "Music, Domestic Life and Cultural Chauvinism: Images of British Subjects at Home in India," in Music and Society: The Politics of Composition, Performance, and Reception, ed. Richard Leppert and Susan McClary (Cambridge, 1987), 95; and Spear, The Nabobs, 98-100.

16 The 53rd (Shropshire) Regiment set out for India in 1805 and served there until 1823. They saw active service in Allahabad and against the Gurkhas of Nepal in 1815-17 and then returned later in the century to fight in both Anglo-Sikh Wars of 1845-46 and 1848-49 and in the Indian Rebellion of 1857. The author gratefully acknowledges Robert Phillips and Paul Courtright for the Hindi translations.

17 R. Siva Kumar, "Modern Indian Art: A Brief Overview," Art Journal 58, 3 (1997), 15.

18 Francis Grose, Rules for Drawing Caricaturas: With an Essay on Comic Painting (London, 1788), 12.

19 Natasha Eaton, "Between Mimesis and Alterity: Art, Gift, and Diplomacy in Colonial India, 1770-1800," Society for Comparative Study of Society and History 46, 4 (2004), 837; and Natasha Eaton, "The Art of Colonial Despotism: Portraits, Politics, and Empire in South India, 1750-1795," Cultural Critique 70 (Fall 2008), 63-93.

20 David S. Solkin, “'Conquest, usurpation, wealth, luxury, famine:' Mortimer's Banditti and the Anxieties of Empire," in Timothy Barringer, Geoffrey Quilley, and Douglas Fordham, eds., Art and the British Empire (Manchester, 2006), 120.

21 For notions of British assimilation and transculturation see William Dalrymple, White Mughals: Love and Betrayal in EighteenthCentury India (London, 2002); William Dalrymple, ed., Begums, Thugs and White Mughals: The Journals of Fanny Parkes (London, 2002); William Dalrymple, "Assimilation and Transculturation in Eighteenth-Century India: A Response to Pankaj Mishra," Common Knowledge 11, 3 (2005), 445-85. Simplistic racial division 
is also being addressed and challenged in the architectural history of Calcutta. See Swati Chattopadhyay, "Blurring Boundaries: The Limits of 'White Town' in Colonial Calcutta," The Journal of the Society of Architectural Historians 59, 2 (June 2000), 154-79.

22 The Times (21 September 1785), 2.

23 Catherine Molineux, "Hogarth's Fashionable Slaves: Moral Corruption in Eighteenth-Century London," ELH 72 (2005), 496.

24 Victor Turner, Blazing the Trail: Way Marks in the Exploration of Symbols, ed. Edith Turner (Tucson and London, 1992), 49. Similarly Saggini describes the liminality of the nabobs as "both alien and native, outsiders as much as insiders" in Francesca Saggini, "The Stranger Next Door: Identity and Diversity on the Late Eighteenth-Century Stage," Restoration and Eighteenth-Century Theatre Research 18, 2 (2003), 2.

25 Gayatri Chakravorty Spivak argued that the most basic tension of empire was that the otherness of colonized peoples was neither inherent nor stable. As cited in Catherine Hall, Civilising Subjects: Colony and Metropole in the English Imagination, 1830-1867 (Chicago and London, 2002), 6-7.

26 "Anxiety" is used here in the inclusive sense suggested by Nigel Leask, which refers to the breadth of reactions to the East, from apprehension to intense yearning, often represented as a fear of contagion. This is based on Sara Suleri's "anxiety of empire," which similarly encompasses a range of behaviours speaking to an insecure sense of imperial desire. Nigel Leask, British Romantic Writers and the East: Anxieties of Empire (Cambridge, 1992); Sara Suleri, The Rhetoric of English India (Chicago, 1992), 1.

27 Jitender Gill, "Servants of the Raj: Colonials and Their Fictions, 1770-1930" (Unpublished PhD Dissertation, University of Southern California, 2004), 2.

28 Mary Douglas, "Powers and Dangers," in Purity and Danger: An Analysis of the Concept of Pollution and Taboo [1966] (New York, 2002), 94.

29 The portraits of Major-General Stringer Lawrence (ca. 1760) by Sir Joshua Reynolds and Admiral Charles Watson and his Son (ca. 1760) by Thomas Hudson are two notable examples.

30 The dress, which has survived and is in the York City Art Gallery, is possibly a khil'at, a type of ceremonial robe bestowed upon subjects by Indian rulers as a part of the durbar ritual, a traditional gift exchange which symbolically incorporated those gifted into the rajah's body. In the nineteenth century, the durbar was appropriated by British rulers, becoming a rite of subordination. See Bernard S. Cohn, Colonialism and Its Forms of Knowledge: The British in India, Princeton Studies in Culture / Power / History, ed. Sherry B. Ortner, Nicholas B. Dirks, Geoff Eley (Princeton, 1996), 129.

31 Mildred Archer, India and British Portraiture 1770-1825 (London, 1979), 216-17. The East India Company had used banyans, Hindu traders and merchants, and shroffs, or financiers, to manage and finance trade in India since their arrival in the seventeenth century. By the late eighteenth and early nineteenth centuries,
British administrators began to mistrust native entrepreneurs and endeavoured to create their own financing agencies to avoid dependence on native industry. For British mistrust of native "practices of bribery, privileges, and partial favors to traders," see Sudipta Sen, Empire of Free Trade: The East India Company and the Making of the Colonial Marketplace, ed. David Ludden, Critical Histories (Philadelphia, 1998), 110.

32 According to Matthew H. Edney, a map of the Indian territory may have been found in a London office as a product of the imperial "knowledge" which facilitated empire. For his important arguments, see Matthew H. Edney Mapping an Empire: The Geographical Construction of British India, 1765-1843 (Chicago, 1997).

33 Archer, India and British Portraiture, 357; de Almeida and Gilpin, Indian Renaissance, 169-70; Beth Fowkes Tobin, Picturing Imperial Power: Colonial Subjects in Eighteenth-Century British Painting (Durham and London, 1999), 110-38.

34 Amelia Faye Rauser, Caricature Unmasked: Irony, Authenticity, and Individualism in Eighteenth-Century English Prints (Delaware, 2008). This image can be viewed online at The British Museum Collections Database Search: Registration no. 1868,0808.9996. [http://www.britishmuseum.org/research/search_the_collection_ database.aspx]

35 Jonathan C.D. Clark, English Society 1688-1832: Ideology, Social Structure and Political Practice During the Ancien Regime (Cambridge, 1985); Frank O'Gorman, The Long Eighteenth Century: British Political and Social History, 1688-1832, The Arnold History of Britain Series (New York, 1997).

36 For an assessment of the problems associated with the shift in the British empire in mid-century as it failed in America but succeeded in Asia, see Peter James Marshall, "A Free Though Conquering People:" Eighteenth-Century Britain and Its Empire (London, 2003).

37 Richard Clarke, The Nabob: Or, Asiatic Plunderers a Satyrical Poem, in a Dialogue between a Friend and the Author. To Which Are Annexed, a Few Fugitive Pieces of Poetry (London, 1773).

38 Cohn, Colonialism and Its Forms of Knowledge, 229.

39 In the mid-eighteenth century, Company civil servants died at a rate of forty-four percent, and though survival had increased by 1800 , those who survived deadly diseases in India would often have lingering and in some cases visible side effects including weakness, yellow skin, liver pain, and biliousness. See Collingham, Imperial Bodies, 13; Peter James Marshall, East Indian Fortunes: The British in Bengal in the Eighteenth Century (Oxford, 1976), 219 and Sudipta Sen, Distant Sovereignty: National Imperialism and the Origins of British India (London, 2002), 126-27.

40 Margot C. Finn, The Character of Credit: Personal Debt in English Culture, 1740-1914 (Cambridge, 2003).

41 Dundas was intimately involved in India-related British politics, and personal misfortune and tragedy may have informed his concern as two of his three brothers who travelled to India in an attempt to make a fortune died. In 1781 he chaired a secret com- 
mittee that inquired into the recent war with Haidar Ali, charged Thomas Rumbold with "pains and penalties," and blamed Warren Hastings for allowing incompetence; three years later, he voted to impeach Hastings for "high crimes and misdemeanours." For a good summary of Dundas's participation in British politics concerning India, see Michael Fry, "Dundas, Henry, First Viscount Melville (1742-1811), Politician,” in H.C.G. Matthew and Brian Harrison, eds., Oxford Dictionary of National Biography (Oxford, 2004). [http://www.oxforddnb.com/view/article/8250?docPos=8, accessed November 25, 2011)]. For Gillray's satirical treatment of Dundas's role in government charges against Rumbold, see Christina Smylitopoulos, "Rewritten and Reused: Imaging the Nabob Through 'Upstart Iconography," Eighteenth-Century Life 32, 2 (2008), 39-59.

42 Smylitopoulos, "Rewritten and Reused," 39-59.

43 Edmund Burke, as quoted in Marshall, "A Free Though Conquering People."

44 Society of Artists of Great Britain, A Catalogue of the Pictures, Sculptures, Designs in Architecture, Models, Drawings, Prints, Etc.: Exhibited at the Great Room in Spring Garden, Charing Cross, April the Twenty-Second, 1767 (London, 1767), number 88, 307.

45 Society of Artists of Great Britain, Le Pour Et Le Contre: Being a Poetical Display of the Merit and Demerit of the Capital Paintings, Exhibited Spring Gardens (London, 1767), 364.

46 Thomas Agnew \& Sons, Ltd., English Life and Landscape: An Exhibition of English Pictures, 1730-1870, 8th March-8th April 1971, 1971, no. 9. The author discusses Wright's poetic licence with the uniform, but says, with respect to an association with India, that "the turban, however, could well by itself have suggested the description." See also Benedict Nicolson, Joseph Wright of Derby: Painter of Light, 2 vols (London, 1968), I, 228.

47 Nicolson, Joseph Wright of Derby, II, no. 154.

48 This painting is now in a private collection. Benedict Nicolson, "Wright of Derby: Addenda and Corrigenda," Burlington Magazine 130, 1027 (October 1988), 749.

49 Desmond Shawe-Taylor, The Georgians: Eighteenth-Century Portraiture and Society (London, 1990), 96.

50 National Portrait Gallery, London, United Kingdom.

51 Hermann Goetz, "Persians and Persian Costumes in Dutch Painting of the Seventeenth Century," The Art Bulletin 20, 3 (September 1938), 280-90.

52 "Sketch of London Fashions," Weekly Entertainer or, Agreeable and Instructive Repository (January 1803), 31. Isabel Breskin, “'On the Periphery of a Greater World:' John Singleton Copley's 'Turquerie' Portraits," Winterthur Portfolio 36, 2/3 (Summer-Autumn 2001), 97-123.

53 Marcia Pointon, "Going Turkish in Eighteenth-Century London," in Hanging the Head: Portraiture and Social Formation in Eighteenth-Century England (New Haven and London, 1993), 141-57.

54 Cassandra Albinson, Peter Funnell, and Luzy Peltz, Thomas Law- rence: Regency Power and Brilliance (New Haven and London, 2010), 213-15.

55 Nabil I. Matar, "Renaissance England and the Turban," in David Blanks, ed., Images of the Other: Europe and the Muslim World Before 1700, Cairo Papers in Social Science 19, 2 (1997), 39-54.

56 Italics mine. "Account of the King of Denmark's Masked Ball," The Gentleman's Magazine (October 1768), 450. Another account of this event is found in "Affairs in England," Scots Magazine (October 1768), 538.

57 “Zulima: An Oriental Tale," British Magazine, or, Monthly Repository for Gentlemen and Ladies (October 1764), 503.

58 Henry Vansittart, "A Description of the Curious Boat, Lately Brought from India, and Presented to Their Majesties by Gov. Vansittart," The Gentleman's Magazine (September 1768), 406. Vansittart was Governor General of Bengal from 1759 to 1764.

59 James Raven, Judging New Wealth: Popular Publishing and Responses to Commerce in England, 1750-1800 (Oxford, 1992), 226.

60 Banditti were, since the early 1770s, bellicose, renegade Englishmen who had adopted what were perceived to be the immoral habits of the East, much like the nabob. The painter and engraver John Hamilton Mortimer (1740-79) often portrayed banditti in turbans, a device which became critical shorthand for "the excesses of modern metropolitan life." Finbarr Barry Flood, "Correct Delineations and Promiscuous Outlines: Envisioning India at the Trial of Warren Hastings," Art History 19, 1 (2006), 47-78. This satire engages with complex issues, not least of which was that Hastings had been unjustly positioned as a scapegoat for those who gained from his arbitrary and despotic approach to rule in India, namely George III and his government; nevertheless, my interest here is in illustrating how graphic satirists had developed conventions in representing Hastings through the use of the turban.

61 Solkin, “'Conquest, Usurpation, Wealth, Luxury, Famine," 123; Martin Myrone, Bodybuilding: Reforming Masculinities in British Art 1750-1810 (New Haven and London, 2005), 130. As interventions into portraiture, Gillray's Market Day (ca. 1788), The Bow to the Throne - alias - The Begging Bow (1788), and Blood on Thunder Fording the Red Sea (1788) and the work of anonymous artists in A Slow and Sure Deliverance, An Anticipation Sketch (1788); Court Cards, the Best to Deal With (1788); and Sublime OratoryA Display of It (1788), among others, are certainly brought to mind.

62 Honoria, The Female Mentor: Or, Select Conversations (London, 1793), 139.

63 Honoria, The Female Mentor, 139.

64 David Kunzle, The Early Comic Strip: Narrative Strips and Picture Satires in the European Broadsheet from c. 1450 to 1825, 2 vols. (Berkeley, Los Angeles, and London, 1973), I, History of the Comic Strip, 388.

65 The notion of respectable paucity was also explored in Henry Mackenzie's The Man of Feeling [1771], ed. Brian Vickers (Oxford, 1967), 102-03. 
66 The potential damage to national interests by the activities of individuals were being explored in the eighteenth century. In a similar argument, John Brewer claims there was an eighteenth-century perception that foreigners, especially the French, disseminated effeminacy under the guise of fashionable manners in an effort to drain the British of their patriotism. John Brewer, Pleasures of the Imagination: English Culture in the Eighteenth Century (London, 1997), 83.

67 Published 4 August 1781 by W. Wells, No. 132 Fleet Street, London. At the Library of Congress, Prints and Drawings Division.

68 The name on the poop of the ship could refer to the Godfrey family, who earlier in the century funded East India Company shipping. See George K. McGilvary, Guardian of the East India Company: The Life of Laurence Sulivan (London, 2006), 34.

69 For a discussion of the trope of industriousness in British colonial projects, see Sarah Jordan, The Anxieties of Idleness: Idleness in Eighteenth-Century British Literature and Culture (Bucknell, 2003), 137.

70 For a discussion of the reality of European men wearing Indian garb and the few examples of portraits reflecting this phenomenon, see de Almeida and Gilpin, Indian Renaissance, 104.

71 Sir Joshua Reynolds, Sir Joshua Reynolds's Discourses (1769-1790), ed. Edward Gilpin Johnson (Chicago, 1891), 90. For a discussion of the mid-century shifts in portraits of gentlemen and Reynolds's attempts to elevate portraiture in the hierarchy of painting through debates on fashion versus nature, see David H. Solkin, "Great Pictures or Great Men? Reynolds, Male Portraiture, and the Power of Art," Oxford Art Journal 9, 2 (1986), 42-49.

72 David Price, Memoirs of the Early Life and Service of a Field Officer, on the Retired List of the Indian Army (London, 1839), 281.

73 Archer, India and British Portraiture, 336; David Price, Memoirs of the Early Life, 281.

74 He visited Alexandria, Cairo, Mocha, Massowa, Hodeida, Bombay, Poona (where this portrait was executed), and Seringapatam, where he joined the fighting against Sultan Fateh Ali Tippu in the Third Anglo-Mysore War. Seton had again been imprisoned, this time for impersonating a doctor, and then trekked three hundred miles on foot from Poona to Chittledroog to seek compensation from Lord Cornwallis. Hugh Seton, Correspondence and legal papers of Hugh Seton of Touch, formerly Smith, Archibald Seton, 13th of Touch, and Barbara Seton, 14th of Touch, 17751831GB233/MS.19204-19209, National Library of Scotland, Ediburgh.

75 Rev. William Tennant, Indian Recreations: Consisting Chiefly of Strictures of the Domestic and Rural Economy of the Mahomedans \& Hindoos (London, 1803), I, 72.

76 Mary Dorothy George, Catalogue of Political and Personal Satires: Preserved in the Department of Prints and Drawings in the British Museum (London, 1949), 6:336; and Draper Hill, Fashionable Contrasts: Caricatures by James Gillray (London, 1966), 169.
77 Examples include Edmund Burke's pejorative "black banyan" and an anonymous author's description of an Anglo-Indian's beebee as "black as soot-Blacker, aye blacker than your boot!" Edmund Burke, The Works of the Right Honourable Edmund Burke (1788) VII (London, 1857), 33-34; Quiz, (William Combe), The Grand Master or the Adventures of Qui Hi? In Hindostan: A Hudibrastic Poem in Eight Cantos by Quiz. Illustrated with Engravings by Rowlandson (London, 1816), 151.

78 Tobin has argued that "cultural cross-dressing" was an indication of the Briton's ability to "master the alien and the exotic," a problematic claim in light of the tensions regarding cultural cross-dressing in India. Tobin, Picturing Imperial Power, 111.

79 Image reproduced in Tillman W. Nechtman, Nabobs: Empire and Identity in Eighteenth-Century Britain (Cambridge, 2010), 201.

80 Archer, India and British Portraiture, 412.

81 As quoted in Nechtman, Nabobs: Empire and Identity, 199. Another example of a woman paying homage to India by hinting at a turban is the portrait of Susanna Wales by her father, James Wales. See de Almeida and Gilpin, Indian Renaissance, 84.

82 Douglas Fordham, "Costume Dramas: British Art at the Court of The Marathas," Representations 101, 1 (2008), 78.

83 Thomas Babington Macaulay, "The Edinburgh Review, 1840, Robert Clive," in Critical, Historical, and Miscellaneous Essays and Poems (n.p., 2009), 453.

84 William Makepeace Thackeray, Vanity Fair, a Novel without a Hero [1848], ed. John Carey (New York, 2004).

85 Figures who assumed the manners of the East include Charles "Hindoo" Stuart (ca. 1758-1828), who converted to Hinduism, Sir David Ochterlony (1758-1825), who commissioned portraits of himself in the guise of an Indian nawab, and James Achilles Kirkpatrick (1761-1805), who adopted many Indo-Persian customs and married a Hyderabad noblewoman, Khair-un-Nissa.

86 The sitter of this portrait had previously been identified as Colonel Donald Macleod, but this association has since been abandoned. For a representation of this painting, see the Yale Center for British Art online catalogue: [http://collections.britishart.yale.edu/ vufind/Record/1667629]. 